\title{
BUDAYA LITERASI DAN INFILTRASI GERAKAN ISLAM RADIKAL DI PESANTREN INDONESIA
}

\author{
Abdul Malik \\ Universitas Islam Negeri Mataram, Indonesia \\ E-mail:abdul.malik@uinmataram.ac.id \\ Tamjidillah \\ Universitas Islam Negeri Mataram, Indonesia \\ E-mail: tamjidillah05@gmail.com \\ Satriawan \\ Universitas Islam Negeri Mataram, Indonesia \\ E-mail: satriawan2000@uinmataram.ac.id
}

\begin{abstract}
Since 2002, the discourse of pesantren has been linked to radicalism. This has led to a new typology of pesantren, namely radical pesantren. This typology of pesantren is usually known to adhere to the Salafi Jihadi ideology. This article examines how Salafi Jihadi pesantrens have radical tendencies. The study mainly focused on the literacy culture that was developed. By using the qualitative-phenomenological method, this article finds that several basic concepts in Islam, in this case, the enforcement of Islamic law and the concept of jihad, have been interpreted in a pejorative way by the Salafi Jihadi pesantren community, thus causing radical and counterproductive understanding and actions to religious values. The Salafi Jihadi pesantren is different from other pesantrens that have been known before. The Salafi Jihadi pesantren teaches not only material on the fiqh of ablution, prayer, or muamalah, but also on jihad and abkam al-dimmah (the law of shedding blood). In addition, it was also found that culture of literacy is apparently not the only factor that determines whether a pesantren can be labelled radical or not, but there are still many other supporting factors, such as the entry of exradicals to pesantren, lack of government control, exclusivity, and doctrinal pedagogy.
\end{abstract}

Keywords: Pesantren; Salafi Jihadi; jihad; Islamic law. 


\section{Pendahuluan}

Sejalan dengan pesatnya peningkatan jumlah pesantren pada dua dasawarsa terakhir, corak dan bentuk pendidikan pesantren juga mengalami perkembangan. Dilihat dari sistem pendidikan dan pengajarannya, pesantren dapat dibagi menjadi tiga model, yaitu pesantren tradisional, modern, dan independen. Namun, dilihat dari paham keagamaan dan ideologi politiknya, pesantren dapat dikategorikan menjadi tradisionalis, modernis, dan belakangan juga muncul kategori fundamentalis dan jihadis. ${ }^{1}$

Kajian tentang pesantren yang pada awalnya menyoroti posisi dan peran pesantren dalam merespons modernitas kini telah bergeser pada keterlibatan pesantren dengan isu-isu radikalisme, terutama pada pascareformasi. Varian pesantren tidak lagi terbatas pada kategori pesantren tradisional yang pada umumnya berafiliasi pada Nahdlatul Ulama (NU) dan pesantren modernis pada Muhammadiyah yang umumnya berhaluan 'Islam lunak', akan tetapi kini juga muncul varian pesantren yang berafiliasi pada organisasi ataupun ideologi gerakan radikal atau 'Islam keras,' sebagaimana tampak pada pesantren-pesantren yang dikenal sebagai pesantren Salafi, yang keberadaannya kini mulai menjamur di banyak wilayah di Indonesia. ${ }^{2}$ Sebagaimana gerakan Salafi, keberadaan pesantren-pesantren tersebut juga terbagi ke dalam beberapa tipe, yaitu pesantren Salafi Haraki, Wahabi, dan Jihadi.

Artikel ini akan difokuskan pada pembahasan tentang pesantren Salafi Jihadi yang selama ini dianggap menggambarkan kelompok gerakan Islam radikal seperti Jemaah Islamiayah (JI), kelompok Jemaah Anshorut Tauhid (JAT), Jemaah Anshorud Daulah (JAD), dan Islamic State in Iraq and Syria (ISIS). Beberapa pesantren yang dikelola oleh kelompok Salafi Jihadi dinilai menyokong radikalisme dengan menggunakan term 'jihad' (jihäad) yang digeneralisasi sebagai jalan dakwah dengan kekerasan. Tak pelak, di samping merugikan keberadaan pesantren, generalisasi tersebut juga membuat konsep jihad sebagai salah satu ajaran yang

${ }^{1}$ Irfan Abubakar dan Idris Hemay (eds.), Resiliensi Komunitas Pesantren terbadap Radikalisme; Social Bonding, Social Bridging, Social Linking (Jakarta: Center For The Study of Religion and Culture [CSRC], 2020).

2 Penjelasan tentang "Salafi," baik dalam konteks bahasa, istilah, maupun gerakan Islam, diambil dari Saeful Anwar, "Geneologi dan Gerakan Militansi Salafi Jihadi Kontemporer," An-Nas; Jurnal Humaniora, Vol. 2, No. 1 (2018), 16984. 
fundamental dalam Islam menjadi peyoratif. Akibatnya, setiap individu atau kelompok yang menjadikan jïhäd fì sabil Alläh (berjuang di jalan Allah) sebagai asas dan metode (manhaj) dakwah dianggap radikal dan fundamentalis. Anggapan tersebut menguat terutama sejak peristiwa pengeboman di Bali pada Oktober 2002, yang melibatkan salah satu alumni pesantren, seperti yang dikatakan Azra dan kawan-kawan, bahwa:

The October 2002 bombings in Bali, Indonesia, in which more than 200 people died, raised concerns in Indonesian and Western policy circles about the possible involvement of some of Indonesia's modern Islamic schools (madrasas) and traditionalist boarding schools (pesantrens) in promoting religious radicalism. Police investigations traced the Bali bombers back to a small pesantren in Lamongan, East Java ${ }^{3}$.

Sejak saat itu, pesantren secara umum dan pesantren Salafi Jihadi secara khusus menjadi sorotan, terutama kurikulum atau budaya literasinya yang dinilai sebagai pro-radikal; budaya litarasi pesantren Salafi Jihadi dianggap menggunakan legitimasi teks sebagai penopang argumentasi yang dibangun.

Budaya literasi pesantren sejatinya menjadi faktor penting yang perlu diteliti terkait dengan penyebaran sel-sel radikalisme dalam tubuh pesantren. Awal stigmatisasi radikal terhadap pendidikan pesantren lebih diakibatkan oleh dua hal, yaitu (1) peran ustaz sebagai figur sentral dalam kultur pesantren (bidden curriculum); dan (2) model literasi atau kurikulum yang diajarkan dalam pesantren tersebut. Dalam wacana keterkaitan antara pesantren dengan paham radikal, dua faktor ini kerap mencuat dan secara langsung atau tidak membangun image yang negatif tentang kurikulum pesantren dan pemahaman Islam. Meskipun stigmatisasi radikal terhadap pesantren ini ditentang oleh banyak pihak, tidak sedikit peneliti Islam dan terorisme di Indonesia terus meyakini bahwa pesantren menjadi salah satu tempat pertumbuhan pemahaman keagamaan yang radikal dan eksklusif. Pesantren dinilai memiliki hubungan dengan perkembangan isu politik global, terutama isu perang terhadap terorisme global yang dipelopori oleh Amerika,

\footnotetext{
3 Azyumardi Azra et al., "Pesantren and Madrasa: Muslim Schools and National Ideals in Indonesia," dalam Robert W. Hefner dan M.Q. Zaman (eds.), Schooling Islam: The Culture and Politics of Modern Muslim Education (Princeton: Princeton University Press, 2007), 172-198.
} 
konstalasi politik agama di Afghanistan, ${ }^{4}$ meningkatnya Islamofobia di Barat, dan meluasnya pengaruh gerakan Islam transnasional. ${ }^{5}$

Artikel ini berusaha menelusuri secara mendalam bagaimana budaya literasi terbangun di lingkungan pesantren Salafi Jihadi. Pembahasan terkait ini perlu dielaborasi lebih jauh mengingat adanya kecurigaan bahwa pesantren tersebut mengajarkan sekaligus menyebarluaskan ideologi radikal. Untuk itu, artikel ini menggunakan pendekatan fenomenologi, dengan mengungkapkan secara mendalam budaya literasi pesantren Salafi Jihadi yang dianggap berbeda dengan pesantren tradisional pada umumnya. Artikel ini menemukan tiga persoalan yang membentuk bangunan literasi yang terus dijaga dan dikembangkan secara konsisten pada pesantren tersebut, di antaranya yaitu: materi tentang jihad, hukum menumpahkan darah (aḅkäm al-dimmah), dan pembicaraan terkait khiläfah Islämìyah. Dengan menelisik bangunan literasi pesantren Salafi Jihadi tersebut, artikel ini juga mencoba untuk menetralkan pemahaman, prasangka, ataupun generalisasi yang kerap kurang tepat terkait tiga persoalan tersebut.

\section{Pesantren Salafi Jihadi}

Konsepsi ideologis Salafi Jihadi lebih banyak dipengaruhi oleh tokoh-tokoh yang mendukung aksi jihadi gobal, seperti Salmān b. Fahd al-'Awdah, Safar al-Ḥawālī, Ayman al-Ẓawāhirī, Sulaymān Abū Ghayth, 'Abd Allāh 'Azzam, Usāmah b. Lādin, serta Mullāh 'Umar. Ulama-ulama tersebut disebut sebagai ulama mujahid. ${ }^{6}$ Menurut F. Gerges (2005), ulama-ulama ini berafiliasi dengan kelompok jihad global al-Qaeda yang dihubungkan dengan peristiwa 11 September. $^{7}$ Pada aspek pemahaman keagamaan atau literasi, kelompok ini merujuk manhaj salaf seperti Ibn b. Bāz, Shaykh al-Albānī dan kelompok mayoritas abl al-Sunnah wa al-

\footnotetext{
4 Ridwan Rosdiawan, "Memetakan Anatomi Diskursus Islamisme dan Terorisme Islam," Islamica: Jurnal Studi Keislaman, Vol. 13, No. 1 (2018), 1-3.

${ }^{5}$ Nava Nuraniyah, "Not Just Brainwashed: Understanding the Radicalization of Indonesian Female Supporters of the Islamic State," Terrorism and Political Violence, Vol. 30, No. 6 (2018), 890-910.

6 Mihai Murariu dan George Anglitoiu, "The Case of Islamic State as a Renovative Totalist Movement The Case of Islamic State as a Renovative Totalist Movement," Terrorism and Political Violence (2019), 1-28.

7 Fawaz A. Gerges, The Far Enemy: Why Jihad Went Global (New York: Cambridge University Press, 2005), 1-2.
} 
jemāah. Amin Abdullah berpendapat bahwa kelompok Salafi Jihadi ini cenderung mengikuti pemahaman keagamaan yang merujuk pada khiläfah Islämìyah dan ajaran al-walä' wa al-barä' yang menganggap kelompok lain (the others) dengan pendekatan takfiriyah (pengkafiran). ${ }^{8}$ Pengkafiran adalah konsep yang diimani oleh kelompok Salafi. Meskipun pengkafiran tersebut bersifat umum, tetapi opini publik menganggap bahwa kelompok Salafi 'gemar' mengkafirkan tanpa mempertanyakan apakah sifatnya umum atau personal. $^{9}$

\section{Gambar 1:}

Pola Pendidikan Eksklusif dan Fase Perubahan Sikap Keagamaan ${ }^{10}$

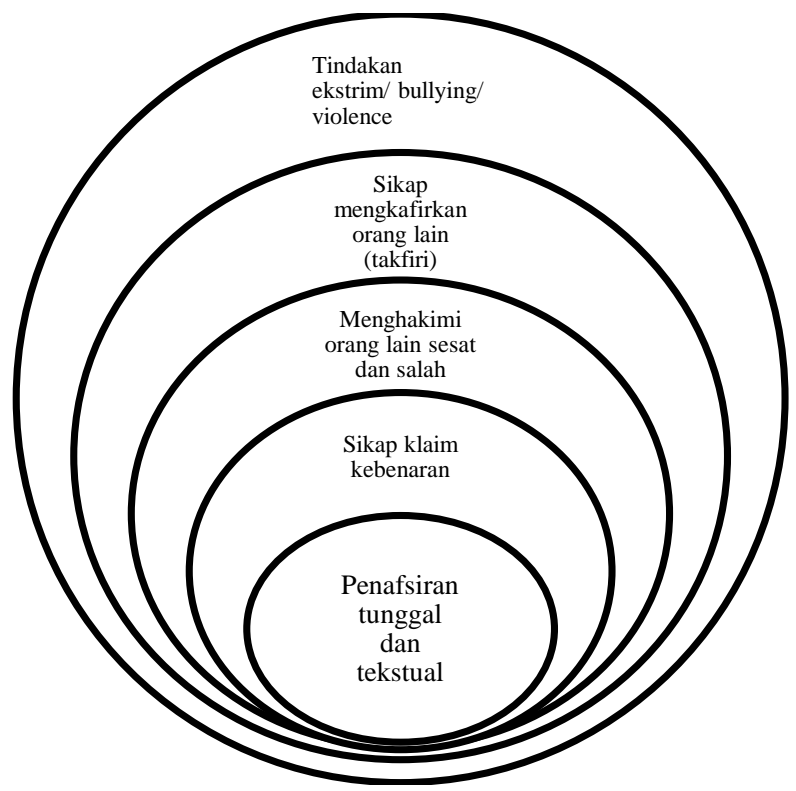

Dalam hal metode dan pendekatan memahami Islam, pesantren Salafi Jihadi dikenal sangat rigid dan eksklusif. Mereka

${ }^{8}$ M. Amin Abdullah, "Islam as a Cultural Capital in Indonesia and the Malay World: A Convergence of Islamic Studies, Social Sciences, and Humanities," Journal of Indonesian Islam, Vol. 11, No. 2 (2017), 307-28.

${ }^{9}$ Anton Minardi, "The New Islamic Revivalism in Indonesia Accommodationist and Confrontationist," Journal of Indonesian Islam, Vol. 12, No. 2 (2018), 247-64.

10 Abdul Malik, "Stigmatization of Islamic School: Pesantrens, Radicalism and Terrorism in Bima," Ulumuna; Journal of Islamic Studies, Vol. 21, No. 1 (2017), 173. 
dikenal tekstual, sehingga melahirkan klaim kebenaran diri, menutup diri, atau bahkan menyalahkan kelompok lain. Harus diakui, bahwa klaim kenebanaran tersebut di satu sisi memiliki dampak posisif bagi kalangan internal kelompok agama, tetapi di sisi lain ia bisa menimbulkan kecenderungan menyalahkan kelompok lain yang berbeda secara pemahaman. Bahkan, pada titik tertentu, klaim kebenaran tersebut bisa menyebabkan kekerasan fisik.

Gambar di atas menjelaskan bahwa beberapa fase di mana individu yang diduga radikal dan kemudian menjadi teroris pada dasarnya berawal dari kondisi individu yang normal. Pada fase "penafsiran tunggal" dan "tekstual," individu atau kelompok cenderung menjadi sasaran indoktrinasi dengan pola-pola yang provokatif, emosional, fanatis, dan eksklusif. Fase tersebut diyakini oleh sebagian pihak sebagai tahap permulaan pemberian pemahaman, cara pandang, dan keyakinan baru terhadap para anggota baru kelompok. Setelah fase radikalisasi pada individu atau kelompok, fase berikutnya individu cenderung menggunakan pola berpikir divergent atau "hitam putih" (jika tidak benar berati salah atau sebaliknya). Cara berpikir tersebut memberikan penilaian atau menghakimi benar atau salah terhadap orang lain menurut sudut pandangnya sendiri. Fase ini merupakan permulaan individu berinteraksi (membuat kontak) dengan lingkungan sekitar dengan mengedepankan kebenaran pemahaman secara subjektif.

Fase selanjutnya adalah sikap takfirì (pengkafiran), di mana pandangan yang menjustifikasi sesat orang lain, berubah menjadi sikap mengkafirkan orang lain yang tidak sepaham. Sikap ini dalam sejarah kelompok ekstremis Islam erat kaitannya dengan hukum halal atau tidak darah seseorang untuk dibunuh sebagai konsekuensi hukum yang telah ditetapkan. Fase takfiri adalah puncak dari pemahaman eksklusif yang dimiliki oleh kelompok radikal. Oleh karena itu, fase ini sering menjadi landasan teologis dalam melakukan jïhäd fi sabïl Alläh, meskipun terminologi takfïri dalam ajaran Islam sejatinya dapat diletakan dalam beragam makna, konteks, dan tujuan.

Merujuk pada data lapangan dalam kajian ini, konsep takfiri atau kafir yang dipahami oleh pesantren Salafi Jihadi secara umum dibagi dua. Pertama, kafir dalam konteks teologis, yakni berkaitan dengan pemahaman konsep 'aqìdat al-Islämiyah (ketauhidan). 
Seseorang atau kelompok yang meyakini, meminta, dan memuja Tuhan selain Allah, maka disebut sebagai kafir. Kedua, konsep kafir yang dilabelkan kepada individu atau kelompok yang tidak menjalankan hukum Allah. Kelompok ini masuk dalam kategori syirik khusus sehingga dapat disebut kafir. Dua pengertian kafir tersebut berkembang dalam pemahaman dan keyakinan mayoritas pengajar atau ustaz di pesantren Salafi Jihadi. Akibatnya, segala bentuk produk hukum dianggap kafir dan kelompok atau individu yang menjalankan dan mempertahankan hukum tersebut disebut täghüt. Demikian pula, seorang pemimpin yang mengabaikan dan menafikan hukum-hukum Allah disebut anșär al-tăghūt (pendukung täghüt). Hal ini berkaitan dengan pemahaman pentingnya perjuangan menegakkan sharī'ah Islam yang dipelajari di pesantren yang bercorak Salafi Jihadi. ${ }^{11}$

Dalam pemahaman ini, tindakan takfiri tidaklah serta-merta berimplikasi atau terjebak pada sikap ekstremisme agama seperti yang dikhawatirkan banyak orang. Sebaliknya, pemahaman tersebut mengandaikan bahwa semakin kuat daya dorong dan daya tekan seseorang atau kelompok melakukan takfiri pada kelompok lain, maka seseorang atau kelompok tersebut dipandang sedang melakukan perbuatan yang diklaim sebagai aksi jihad. Meskipun pesantren Salafi Jihadi di Indonesia tidak signifikan jumlahnya dibandingkan pesantren-pesantren bercorak tradisionalis ataupun modernis, akan tetapi ia merupakan corak pesantren yang paling disoroti publik dalam konteks radikalisme. Terlepas dari penolakan komunitas pesantren Salafi Jihadi terhadap tuduhan radikal, tidak dapat dipungkiri bahwa secara umum mereka mengakui bahwa pesantren yang bersangkutan mengajarkan jihad, bercita-cita ingin mewujudakan sharíah Islam, dan menolak sistem pemerintahan yang tidak berdasarakan pada hukum Allah. ${ }^{12}$

Secara faktual, akhir-akhir ini performa pesantren yang bercorak Salafi Jihadi terbilang landai seiring terus menguatnya tekanan dari pemerintah. Pensantren Salafi Jihadi kini sangat jarang tampil secara terbuka sebagai lembaga yang mempresentasikan nilai-nilai yang dianggap radikal. Ia lebih banyak hadir sebagai

\footnotetext{
11 Ibid.

12 Mohamad Salik, "Conserving Moderate Islam in Indonesia: An Analysis of Muwafiq's Speech on Online Media," Journal of Indonesian Islam, Vol. 13, No. 2 (2019), 373-94.
} 
individu-indvidu yang memperjuangkan klaim kebenarankebenarannya sendiri.

\section{Muatan Literasi Pesantren Salafi Jihadi}

Literasi di dunia pesantren bisa dibuktikan dengan kitab-kitab yang ditulis oleh para pengarang berlatar-belakang pesantren. Artinya, budaya literasi pesantren memang tidak lepas dari dunia literasi yang dibangun oleh para ulama terdahulu. Salah satu budaya literasi pesantren yang populer adalah kitab kuning. Bagi kalangan pesantren, istilah kitab kuning bukanlah istilah asing, bahkan ia menjadi identitas keaslian dari pesantren itu sendiri. ${ }^{13}$ Namun, diskursus budaya literasi pesantren kini tidak lagi berfokus pada kitab kuning, tetapi mulai bergeser pada pemikiran-pemikiran modern yang diwariskan oleh para sarjana Muslim kekinian melalui literasi baru atau literasi informasi. ${ }^{14}$

Budaya literasi sangat mempengaruhi cara pandang komunitas masyarakat yang terlibat, termasuk pula dalam hal ini budaya literasi di pesantren. Hampir semua sikap masyarakat pesantren, baik dalam hal keagamaan, sosial, politik dan lainnya, mendapatkan presedennya dalam budaya literasi yang dikembangkan. Sikap moderat atau bahkan intoleran yang ditunjukkan masyarakat pesantren sangat bergantung pada sumber-sumber bacaan atau kurikulum yang ada. Untuk menyebut contoh, kurikulum pendidikan pesantren tradisional merupakan aspek yang diekstraksikan atau dikembangkan dari ideologi dan pemahaman agama kelompok yang bercorak abl al-Sunnah wa al-jemāah, sebagaimana ditunjukkan oleh kitab-kitab dan tokoh-tokoh yang dirujuk. Dengan demikian, bisa dimaklumi jika budaya literasi pesantren tradisional seringkali mengintrodusir gagasan-gagasan dari para pendiri, pengelola pondok, dan bahkan organisasi yang membawahi pesantren itu sendiri.

Demikian pula, kurkikulum pesantren sejauh ini diduga sebagai dasar berkembangnya nilai-nilai radikalisme di pesantren. Muatan kurikulum menjadi salah satu aspek penting yang dijadikan indikator untuk melihat adanya unsur-unsur radikalisme dalam

\footnotetext{
13 Abu Maskur, "Pengutan Budaya Literasi di Pesantren," IQ (Ilmu Al-qur'an): Jurnal Pendidikan Islam, Vol. 2, No. 1 (2019), 232-233.

${ }^{14}$ Rully Khairul Anwar et al., "Pengembangan Konsep Literasi Informasi Santri: Kajian di Pesantren Arafah Cililin Bandung Barat," Wawasan: Jurnal Ilmiah Agama dan Sosial Budaya, Vol. 2, No. 1 (2017), 135.
} 
pembelajaran pesantren. Paling tidak, terdapat empat aspek kurikulum yang sangat terkait erat dengan budaya literasi. Empat aspek yang dimaksud adalah: (1) tujuan-tujuan yang ingin dicapai oleh pendidikan itu sendiri; (2) pengetahuan, informasi-informasi, data-data, aktivitas-aktivitas, serta pengalaman-pengalaman dari mana kurikulum itu dibangun; (3) metode atau tata cara yang digunakan oleh para guru dalam mengajar; dan (4) metode atau instrumen yang digunakan oleh guru dalam melakukan penilaian.

Merujuk pada konsepsi kurikulum tersebut, maka sejauh mana budaya literasi pesantren diupayakan akan tampak jelas lewat kurikulum yang diberlakukan di pesantren tersebut. Budaya literasi pesantren tradisional secara umum mengacu pada isi materi yang terkandung dalam kitab kuning yang katalognya ditentukan oleh pengasuh pesantren; ${ }^{15}$ kitab apa saja yang harus dipelajari dan instrumen apa yang harus digunakan. Hal tersebut juga menggambarkan kompetensi yang harus dicapai oleh santri. ${ }^{16}$

Menurut Karel A. Steenbrink, pada abad ke-19 literasi pesantren hanya mengenal materi figh, tata bahasa Arab, Ușūl alDīn, tasawuf, dan tafsir. Namun, seiring dengan perkembangan zaman, dan di tengah pertarungan beragam model ideologi, kini pesantren dituntut untuk bisa survive dengan identitasnya. Dalam konteks ini, pesantren tidak hanya menghadapi tuntutan untuk mempertahankan kurikulum klasik, nilai, maupun tradisi atau khazanah intelektual Islam, tetapi juga menghadapi tantangan globalisasi dengan segala perangkatnya. ${ }^{17}$ Salah satu tantantang pesantren di era globalisasi ini adalah masifnya perkembangan pengetahuan dan ideologi keagamaan transnasional yang tidak terbendung, ${ }^{18}$ dalam hal ini ideologi kelompok Islam jihadis global.

Kelompok jihadis global dikenal dengan usaha kerasnya untuk memikirkan Islam sebagai sebuah ideologi politik yang mencakup seluruh kehidupan sosial. Bagi kelompok Islamis, masyarakat

\footnotetext{
15 Iswahyudi dan Udin Safala, "Ideologi Argumen-argumen Tradisi Lingkaran Hidup dalam Kitab Kuning," Islamica: Jurnal Studi Keislaman, Vol. 14, No. 1 (2019), 5-6.

${ }_{16}$ Maskur, "Penguatan Budaya Literasi," 234.

${ }_{17}$ M. Shodiq, "Pesantren dan Perubahan Sosial," Jurnal Sosiologi Islam, Vol. 1, No. 1 (2011), 119.

18 Ali Nurdin dan Maulidatus Syahrotin Naqqiyah, "Model Moderasi Beragama Berbasis Pesantren Salaf,” Islamica: Jurnal Studi Keislaman, Vol. 14, No. 1 (2019), 87.
} 
adalah suatu totalitas yang merefleksikan kesatuan komunitas orang-orang beriman pada keesaan Tuhan. ${ }^{19}$ Oleh karena itu, satusatunya indikator apakah kurikulum pesantren memiliki muatan radikal atau tidak dapat dilihat dari ideologi yang diusung. Ideologi tersebut sangat berkaitan dengan para pengajar dan pengelola pesantren. Bagaimanpun, muatan kurikulum adalah turunan dari kesadaran kolektif yang kemudian dikristalisasi menjadi ideologi. bahwa:

Merujuk pada pandangan Husniyatus Salamah Zainiyati,

Based on the idea of the sociology in education, educational institutions should at least have three aspects. First is the ideological values as the school, as the educational institution, should have ideological values. Second, the format of knowledge that begun so general in frame and then screened to be selected in accordance with the purpose of the educational institutions. Third, the educators who run the selection process of the transmission of the science. ${ }^{20}$

Oleh karena itu, pesantren sebagai lembaga pendidikan yang menyuarakan ideologi yang diusungnya, dengan beragam cara, termasuk lewat bangunan kurikulumnya, merupakan suatu kondisi yang tidak terhindarkan. Selama ini, mayoritas pesantren yang bercorak Salafi Jihadi lebih banyak membuat kurikulum secara internal tanpa mengikuti formulasi kurikulum yang disedikan pemerintah. Meskipun kondisi ini merupakan hal yang biasa dalam tradisi pesantren, namun ia sering kali menjadi dasar penilaian bahwa gerakan Islamis disebarkan secara kelembagaan. Trend perubahan orientasi muatan kurikulum pada pesantren Salafi Jihadi, dalam pengertian toleran menuju radikal, disebabkan oleh dua hal. Pertama, adanya kurikulum tersembunyi yang dijalankan baik secara kelembagaan maupun yang dilakukan secara sporadis oleh aktor pengajar tanpa didukung oleh lembaga pesantren secara sistemik. Kedua, adanya pemahaman ideologis para pengajar di pesantren. Pemahaman bias ideologis ini, ditransfer dari pengajar

19 Juan Carlos Antúnez dan Ioannis Tellidis, "The Power of Words: The Deficient Terminology Surrounding Islam-Related Terrorism," Critical Studies on Terrorism, Vol. 6, No. 1 (2013), 126.

20 Husniyatus Salamah Zainiyati, "Curriculum, Islamic Understanding and Radical Islamic Movements in Indonesia," Journal of Indonesian Islam, Vol. 10, No. 2 (2016), 302. 
ke peserta didik atau santri dan mengarah ke cara-cara yang dengannya pandangan mereka dibentuk atau bahkan diubah.

\section{Infiltrasi Paham dan Gerakan Islam Radikal di Pesantren}

Ada beberapa pintu masuk paham radikal ke dalam pesantren. Salah satunya adalah diterimanya mereka yang eks radikal masuk ke pesantren, baik sebagai tenaga pengajar maupun sekadar tinggal di sekitar lingkungan pesantren dan berkesempatan bergaul dengan ustaz atau santri. Pesantren As-Salam (Salafi Jihadi) di Bima, Nusa Tenggara Timur, adalah salah satu pesantren yang dikelola oleh eks radikal yang telah melewati hukuman penjara. Beberapa anak-anak muda yang disinyalir radikal tinggal di sekitar pesantren, bergaul baik intens maupun tidak, dengan anggota komunitas pesantren. Menurut pengakuan pengelola pesantren ini, pandangan dan sikap politik mereka tidak lagi seradikal sebelumnya. Artinya, mereka telah mengalami proses deradikalisasi. Namun, persepsi mereka tentang sistem demokrasi sebagai produk kafir dan harapan akan penerapan sharī'ah oleh negara, walaupun bukan dengan cara-cara revolusioner, menunjukkan benih-benih itu masih ada. Demikian pula, kontak yang intens dengan mereka yang masih bergabung dengan ISIS dan jaringan radikal lainnya meningkatkan faktor risiko. $^{21}$

Selain itu, menguatnya perasaan bahwa Islam terkepung oleh musuh-musuhnya juga menambah faktor risiko. Kondisi psikologis ini dapat dirasakan dalam pernyataan Ustaz Zaber di bawah ini:

Jadi, jangan pernah bermimpi Islam itu gak punya musuh. Ya gak mungkinlah. Begitu juga yang saya katakan pada teman-teman yang ngaji bid'ah itu. Ente-ente itu mimpi, di Islam cari aman, itu mimpi. Kalau kita ingin membawa ajaran yang pernah diajarkan Rasulullah, kita juga harus bisa menerima apa yang diterima oleh Rasulullah. Rasulullah itu pernah dikatakan sähirun majnün (tukang sihir), kamu itu al-säbir (pemecah belah). Beliau dimusuhi, dilempari batu sampai berdarah. Berdakwah di Mekkah 13 tahun banyak ditentang keluarganya. ${ }^{22}$

Keterhubungan dengan pemerintah yang intens dan produktif juga sangat menentukan infiltrasi paham keagamaan radikal di pesantren. Keterhubungan yang kuat antara pesantren dan pemerintah menjadi faktor pelindung yang dapat mengimbangi

\footnotetext{
21 Anwar, Wawancara, Bima, 4-18 Agustus 2019.

22 Ustaz Zaber, Wawancara, Bima, 27 Juli 2019.
} 
faktor risiko. Di pesantren-pesantren yang demikian, keyakinan tentang khiläfah Islämiyah sebagai hadiah dari Allah yang harus ditegakkan dengan kekerasan mulai mengalami pergeseran - untuk tidak menyebut tidak muncul sama sekali, sebagaimana pula terjadi pada keyakinan tentang perjuangan menegakkan shari'ah Islam dan jïhäd fi sabil Allāh.

Jika bukan pada pemerintah, keterhubungan pesantren yang dimaksud juga berlaku pada organisasi masyarakat mainstream berhaluan moderat di tanah air, seperti Muhammadiyah dan NU. Untuk menyebut contoh, taruhlah pesantren Muhammadiyah seperti Pesantren Darul Arqam di Jawa Tengah dan Banten. ${ }^{23}$ Meski memiliki faktor risiko masuknya paham radikal, bahkan beberapa anggota eks organisasi radikal Negara Islam Indonesia (NII) juga ditampung untuk berkhidmat mengajar di pesantren ini, akan tetapi risiko bisa diminimalisir dengan adanya kebijakan internal yang melarang mereka mengajarkan paham atau ideologinya. Kontrol dan pembangunan resiliensi yang dijalankan secara konstruktif oleh Pengurus Pusat (PP) Muhammadiyah akan meningkatkan ketahanan dan menjadi faktor pelindung, sehingga intervensi pemerintah secara langsung tampaknya tidak terlalu dibutuhkan. Mendukung dan memberikan kepercayaan kepada organisasi masyarakat, dalam hal ini PP Muhammadiyah, akan lebih menjanjikan. Lebih-lebih pada 2015 PP Muhammadiyah membangun strategi ketahanan secara internal dengan merilis secara resmi konsep tentang Negara Kesatuan Republik Indonesia (NKRI) sebagai Där al-'Ahd wa al-Shabädah yang menjadi rujukan banyak pesantren yang berada di bawah naungannya.

Hal yang kurang lebih sama juga terjadi pada pesantrenpesantren yang berafiliasi NU yang juga tidak bisa serta-merta lepas dari faktor risiko masuknya pengaruh Hizbut Tahrir Indonesia (HTI). Pesantren An-Nizomiyah di Banten, misalnya, yang terkenal memiliki wawasan kebangsaan yang kuat pun tidak luput dari penetrasi ideologi khilafah HTI. Diakui oleh pimpinannya, bahwa ideologi HTI masuk bukan lewat pesantren, tetapi melalui sekolah yang dikelola oleh Pesantren An-Nizomiyah. Beberapa guru telah diidentifikasi terpengaruh paham radikal. Namun, sikap pimpinan pesantren yang tegas menolak dan menindak tegas pengajar yang

23 Abdul Nasir, Wawancara, Banten, 4-20 Agustus 2019. 
menyalahi ketentuan pesantren meningkatkan faktor pelindung dan menguatkan ketahanan pesantren akan paham radikal. ${ }^{24}$

Selanjutnya, pengaruh alumni pesantren juga bisa menyediakan jalan bagi infiltrasi paham radikal di pesantren. Hal tersebut terjadi pada Pesantren Bahrul Ulum di Goa, Sulawesi Selatan. Infiltrasi paham radikal tersebut disebabkan oleh fakta bahwa beberapa alumninya terpengaruh ke dalam gerakan HTI. Kontak antara mereka dengan santri-santri dapat meningkatkan faktor risiko di dalam pesantren. Sejauh ini, belum diketahui apa staretegi internal pesantren dalam meningkatkan faktor pelindung dari persoalan radikalisme.

\section{Sikap Eksklusif dan Pedagogi Indoktrinatif}

Ada dugaan masuknya paham radikal pada pesantren Salafi Jihadi dikarenakan oleh sikap eksklusif, intoleran, dan minimnya kesempatan untuk terhubung dengan perbedaan dan keragaman identitas, sehingga pesantren Salafi memiliki faktor risiko yang tinggi. Hal ini tergambar pada kebijakannya yang tidak memberikan akses kepada santri untuk membaca buku-buku pemikir keagamaan Indonesia, ditambah lagi keberadaan pesantren yang tidak terhubung dengan ormas-ormas Islam di Indonesia yang berhaluan Islam moderat. Sikap eksklusif dan pedagogi yang indoktrinatif, dalam hal ini budaya literasi pesantren Salafi Jihadi yang tidak mengizinkan santri belajar filsafat dan tasawuf serta literatur-literatur yang tidak sesuai manhaj Salafi Jihadi, semakin meningkatkan faktor risiko.

Untuk menyebut contoh berdasarkan data di lapangan, salah satu pesantren yang berafiliasi dengan paham Salafi adalah pesantren Persis di Bangil, Jawa Timur. Pesantren ini memiliki risiko, karena sikapnya yang eksklusif yang ditandai dengan minimnya relasi pesantren tersebut dengan ruang-ruang perbedaan dan keragaman yang ada. Tingkat risiko ini semakin tinggi akibat keterputusan kultural dan struktural antara pesantren Persis Bangil dengan Persis. Namun, penekanan para tenaga pendidikan di Persis terhadap debat dan adu argumentasi yang konsisten menjadi faktor pengimbang dari sikap pesantren yang terbilang eksklusif. ${ }^{25}$

\footnotetext{
${ }^{24}$ KH. Khatibul Umam, Wawancara, Banten, 4-20 Agustus 2019.

${ }^{25}$ Syamsul Huda, W awancara, Bangil, 4-20 Agustus 2019.
} 
Di antara identitas literasi kelompok Salafi Jihadi yang populis adalah penerapan shari'ah Islam (Islamic law). Kelompok tersebut mejadikan shari'ah Islam sebagai dasar ideologi gerakan. Haedar Nashir mengatakan bahwa shari'ah Islam merupakan hukum Tuhan yang diturunkan untuk mengatur kehidupan manusia secara total. ${ }^{26}$ Pemahaman seperti ini seringkali diklaim oleh kelompok Islam tertentu untuk pembenaran terhadap suatu gerakan politik. Implikasi dari hal tersebut, Islam menjadi serba legal-formal sebagaimana prinsip al-ahkeam al-khamsah (lima asas hukum Islam). ${ }^{27}$ Gerakan Islam sharī'ah merupakan gerakan keagamaan yang sistematis, terorganisir, serta menempuh jalur dari atas ke bawah (top-down) dan dari bawah ke atas (bottom-up) secara sinergis. Ditambah lagi daya militansi yang tinggi menyebabkan gerakan tersebut mendapat tempat tersendiri pada kelompok Islam yang dianggap radikal. Daya militansi tersebut terbentuk dari pandangan dunia (world view) yang bersenyawa dengan aspek-aspek situasional. Hal tersebut merefleksikan persoalan dinamika Islamisasi dan ideologisasi Islam di Indonesia sejak awal kebangkitan nasional hingga era reformasi yang diwarnai pergumulan kelompok Islam dalam kancah politik nasional. ${ }^{28}$

Namun, untuk saat ini, hal tersebut sulit untuk dibuktikan, mengingat sebagian besar masyarakat didahului rasa takut, prasangka, dan bahkan menolak isu penerapan sharíah Islam tanpa memahami dan mengenal secara mendalam tentang manfaat, tujuan, dan nilai yang terkandung di dalamnya. Lebih-lebih, penerapan shari'ah Islam selama ini hanya disorot dari sisi-sisi yang dianggap negatif, misalnya persoalan potong tangan, cambuk, rajam, dan lainnya.

Bagi pesantren yang mendukung penerapan shari'ah Islam, menegakkan nilai-nilai Islam seperti keadilan sosial dalam kehidupan masyarakat memerlukan penerapan shari'ah Islam secara käffah (utuh) terlebih dahulu. Tak pelak, wacana penerapan sharî́ah Islam sering dikaitkan dengan isu-isu politis. Formalisasi hukum Islam tampak diproyeksikan sebagai pengganti dasar

\footnotetext{
${ }^{26}$ Haedar Nashir, Gerakan Islam Syariat: Reproduksi Salafiyah Ideologis di Indonesia (Jakarta: PSAP Muhammadiyah, 2007), 130.

${ }^{27}$ Fawaizul Umam, Reposisi Islam Reformulasi Ajaran (Mataram: LEPPIM, 2011), 202-205

${ }^{28}$ Ibid., 229-210.
} 
negara; bahwa sharī'ah Islam menjadi upaya yang ditujukan tidak hanya bagi terlaksananya sharíah itu sendiri, akan tetapi juga menjadikan sharīah tersebut sebagai sumber hukum bagi semua perundangan yang berlaku melalui keputusan politik. ${ }^{29}$ Semangat formalisasi sharī'ah Islam tersebut, terutama bagi kelompok Islam yang dianggap radikal selama ini, didasarkan pada keyakinan bahwa shari'ah Islam adalah aturan hukum yang sudah sempurna. ${ }^{30}$ Oleh sebab itu, sebagian kelompok Islam memandang bahwa sharí‘ ah Islam patut diperjuangkan.

Merujuk pada pandangan kelompok tersebut, maka dalam artikel ini shari'ah Islam dilihat sebagai salah satu elemen fundamental dalam Islam yang terus melekat pada citra kelompok radikal. Citra tersebut berbeda dengan kelompok lainnya yang memandang penerapan shari'ah Islam tidak hanya sebagai kepentingan politik semata, akan tetapi merupakan kewajiban setiap manusia yang beriman untuk menunaikannya sebagai bentuk ketaatan dan ketundukan manusia terhadap Allah.

Jihad merupakan salah satu dari sekian banyak ajaran fundamental Islam sekaligus pandangan politik yang paling populer terkait isu radikalisme agama dan perang terhadap terorisme. Dalam al-Qur'ān dan Hadīth, jihad dipandang sebagai salah satu pilar penting dalam ajaran Islam. Oleh karena, itu kata "jiha àd" sering disampaikan dalam bentuk fi' amr (kata perintah), dan dalam Islam memiliki banyak makna dan penafsiran. Oleh karena itu, bagi umat Islam konsep jihad menjadi tema yang krusial sekaligus mengundang polemik jika dikaitkan dengan diskursus radikalisme. Perdebatan dan kontroversi atas konsep jihad ini tidak jauh berbeda dengan konsep khiläfah. Kontroversi istilah atau konsep jihad tersebut lebih banyak berkisar pada persoalan makna jihad, hukum, bentuk, waktu, dan konteks (lokus) jihad.

Pada perkembangan selanjutnya, pandangan terhadap konsep jihad sangat tergantung pada kepentingan kelompok yang mendefinisikan. Merujuk pada pendapat Imam Samudra, secara harfiah jihad berarti memberikan yang terbaik, mengeluarkan tenaga untuk mencapai tujuan. Dalam hal ini, usaha seseorang yang

\footnotetext{
${ }^{29}$ Shaykh Ahmad al-Ṭayyib, Jihad Melawan Teroris; Meluruskan Kesalapaham tentang Khilafah, Takfiri, Jihad, Hakimiyah, Jahiliyah, dan Ekstrimisme (Jakarta: Lentera Hati, 2016), 31-33.

${ }^{30}$ Ibid., 83-85.
} 
mencari jalan dapat dikategorikan sebagai jihad. Jihad mengandung arti melakukan yang terbaik untuk menegakan hukum Allah atau berjuang di jalan Allah (jïhäd fì sabil Alläb). ${ }^{31}$ Pendapat Imam Samudra tersebut tidak jauh berbeda dari definisi dan kesepakatan para ulama terdahulu terutama pendiri empat mazhab fiqh (Hanafi, Mālikī, Shāfi'î, dan Hanbalī). Sementara jihad bagi kelompok Khawārij dipandang sebagai kewajiban "perang suci" dan ditempatkan sebagi rukun keenam dalam Islam. Kelompok tersebut meyakini bahwa jihad memiliki peranan penting dalam pengembangan Islam. ${ }^{32}$ Kebanyakan makna jihad ini didefinisikan secara ketat oleh sebagian kelompok Islam radikal seperti 'Abd Allāh 'Azzām, pelopor gerakan jihad internasional, dalam karyanya Tarbìyah Jihädìyah (Pendidikan Jihad). Ia mengatakan bahwa jihad memiliki kedudukan lebih tinggi dari haji, puasa, dan salat. Artinya, ketika datang waktunya jihad, maka semua ibadah-ibadah tersebut dapat ditangguhkan. ${ }^{33}$

Dalam konteks sekarang ini, istilah jihad telah begitu melekat dengan kelompok Islam radikal, sehingga pada perkembangannya konsepsi jihad mengalami perubahan seiring terjadinya peristiwa teror yang dilakukan oleh para jihadis. Perintah dan makna jihad yang suci melebur dalam konotasi dan kosa kata baru seperti "bunuh diri," "perang," "bom," dan "pedang" atau "senjata." Menurut Ibn al-Qayyim, jihad dalam arti yang luas tercermin dari perjalanan hidup dan dakwah Nabi Muhammad. Hal tersebut dinyatakan oleh Ibn al-Qayyim: ${ }^{34}$

Nabi Muhammad, berada pada puncak penguasaan jihad. Beliau menguasai semua macam jihad. Beliau mempraktikkan jihad di jalan Allah dengan sepenuh hati dan fisiknya, melalui dakwah dan penerangan, serta dengan pedang dan tombak. Masa hidupnya semua didedikasikan untuk jihad, dengan perasaannya, pidatonya, dan aksinya. Beliau adalah ciptaan Allah yang terunggul dan mempunyai kedudukan yang paling mulia di sisiNya.

31 Imam Samudra, Aku Melawan Teroris (Solo: Al-Jazeera, 2004), 11.

32 Philip K. Hitti, History of The Arabs: From the Earliest Time to the Present (New York: Palgrave Macmillan, 2002).1

33 As'ad Said Ali, Al-Qaeda; Tinjanan Sosial-Politik, Ideologi, dan Sepak Terjangnya (Jakarta: LP3ES, 2004), 241-243.

34 Muhammad Haniff Hassan, Teoris Membajak Islam; Meluruskan Jihad Sesat Imam Samudra dan Kelompok Islam Radikal (Jakarta: Grafindo Khasana Ilmu, 2007).109 
Merujuk pada definisi di atas, tampak bahwa jihad merupakan salah satu kewajiban bagi kaum Muslimin sebagai jalan untuk taat kepada Allah. Hal ini perlu dilakukan agar jihad yang ditempuh sesuai dengan tuntutan al-Qur'ān dan Ḥadīth sebagai kewajiban ibadah sekaligus ujian bagi orang-orang yang beriman. Selain itu, jihad harus dilakukan semata-mata sebagai bentuk ketaatan kepada perintah Allah, ${ }^{35}$ bukan justru terjebak pada perilaku ekstemisme agama. Akhirnya, dari kajian terhadap budaya literasi pesantren Salafi Jihadi dalam yang mencakup persoalan khiläfah, jihad, dan sharī'ah Islam, diduga bahwa bahwa kehadiran kelompok pesantren Salafi Jihadi menjadi representasi dari gerakan Islam politik. ${ }^{36}$

\section{Penutup}

Budaya literasi pesantren Salafi Jihadi pada umumnya mengintrodusir gagasan dan ideologi keislaman yang sudah dibentuk oleh para pengurusnya, sehingga lembaga tersebut cenderung tidak peka terhadap problem sosial maupun kultural masyarakat. Pesantren seperti ini biasanya lebih tertutup terhadap lingkungan sekitar. Pemahaman keagamaannya lebih eksklusif dan tidak pernah melibatkan masyarakat dalam aktivitas; terjadi kesenjangan sosial dan ideologis antara pesantren dan masyarakat. Akibatnya, rentan terjadi konflik antara masyarakat dengan pesantren tersebut.

Pesantren Salafi Jihadi dewasa ini tidak lagi bersifat homogen sebagaimana pada masa-masa awal, sehingga tidak mudah membuat stigma tunggal terhadap pesantren ini. Meskipun demikian, bukan tidak mungkin ada pesantren yang memiliki pandangan radikal dan menjadi "sarang" teroris karena memiliki jaringan dengan kelompok-kelompok radikal di luar pesantren.

Pada sisi lain, heterogenitas pendidikan pesantren tersebut tidak hanya berkaitan dengan ideologi, metode, keilmuan, maupun tujuannya, akan tetapi juga kurikulum yang dilaksanakan di dalamnya. Pesantren tradisional Salafi Jihadi misalnya, merupakan satu di antara banyak varian pesantren yang mengalami perkembangan dan perubahan, sehingga pesantren tersebut

\footnotetext{
35 Al-Tayyib, Jihad Melawan Teroris, 153-154.

${ }^{36}$ M. Djafar Alamsyah, (In)Toleransi: Memahami Kebencian dan Kekerasan atas Nama Agama (Jakarta: PT. Gramedia, 2018), 244-245.
} 
memiliki perbedaan dengan pesantren tradisional lainnya. Ciri utama dari budaya literasi pesantren Salafi Jihadi adalah mengajarkan fiqh jihad hingga bab aḅkäm al-dimmah (hukum penumpahan darah) dan khiläfah Islämìyah, meskipun keduanya tidak bisa sepenuhnya dapat dikaitkan dengan radikalisme yang notabene adalah produk politik.

Keberdaaan budaya literasi pesantren pada dasarnya bukanlah satu-satunya faktor determinan yang menentukann apakah suatu pesantren itu radikal atau tidak, melainkan masih banyak faktorfaktor lainnya. Faktor hubungan pesantren dengan masyarakat sekitar dan relasi pesantren dengan masyarakat juga dapat menjadi indikator untuk melihat adanya radikalisme dalam tubuh pesantren. Bagaimanapun, keberadaan konten kurikulum suatu pesantren berkaitan erat dengan kebutuhan masyarakat. Umumnya, pada kurikulum lembaga pendidikan pesantren tradisional, materi fiqh mendapat porsi yang lebih dominan karena masyarakat yang dihadapi pesantren menuntut jawaban-jawaban yang jelas terhadap problem keagamaan yang dihadapi. Realitas tersebut menunjukan bahwa eksistensi pesantren tradisional tidak terpisah dengan tuntutan kebutuhan masyarakat sekitar.

\section{Daftar Rujukan}

Abdullah, M. Amin. "Islam as a Cultural Capital in Indonesia and the Malay World: A Convergence of Islamic Studies, Social Sciences, and Humanities," Journal of Indonesian Islam, Vol. 11, No. 2, 2017.

Abubakar, Irfan dan Idris Hemay (eds.). Resiliensi Komunitas Pesantren terhadap Radikalisme; Social Bonding, Social Bridging, Social Linking. Jakarta: Center for the Study of Religion and Culture (CSRC), 2020.

Alamsyah, M. Djafar. (In)Toleransi: Memahami Kebencian dan Kekerasan atas Nama Agama. Jakarta: PT. Gramedia, 2018.

Ali, As'ad Said. Al-Qaeda; Tinjanan Sosial-Politik, Ideologi, dan Sepak Terjangnya. Jakarta: LP3ES, 2004.

Antúnez, Juan Carlos dan Ioannis Tellidis. "The Power of Words: The Deficient Terminology Surrounding Islam-Related Terrorism," Critical Studies on Terrorism, Vol. 6, No. 1, 2013.

Anwar, Rully Khairul et al. "Pengembangan Konsep Literasi Informasi Santri: Kajian di Pesantren Arafah Cililin Bandung 
Barat," Wawasan: Jurnal Ilmiah Agama dan Sosial Budaya, Vol. 2, No. 1, 2017.

Anwar, Saeful. "Geneologi dan Gerakan Militansi Salafi Jihadi Kontemporer," An-Nas; Jurnal Humaniora, Vol. 2, No. 1, 2018.

Azra, Azyumardi et al. "Pesantren and Madrasa: Muslim Schools and National Ideals in Indonesia," dalam Robert W. Hefner dan M.Q. Zaman (eds.), Schooling Islam: The Culture and Politics of Modern Muslim Education. Princeton: Princeton University Press, 2007.

Gerges, Fawaz A. The Far Enemy: Why Jihad Went Global. New York: Cambridge University Press, 2005.

Hassan, Muhammad Haniff. Teoris Membajak Islam; Meluruskan Jihad Sesat Imam Samudra dan Kelompok Islam Radikal. Jakarta: Grafindo Khasana Ilmu, 2007.

Hitti, Philip K. History of The Arabs: From the Earliest Time to the Present. New York: Palgrave Macmillan, 2002.

Iswahyudi dan Udin Safala. "Ideologi Argumen-argumen Tradisi Lingkaran Hidup dalam Kitab Kuning," Islamica: Jurnal Studi Keislaman, Vol. 14, No. 1, 2019.

Malik, Abdul. "Stigmatization of Islamic School: Pesantrens, Radicalism and Terrorism in Bima," Ulumuna; Journal of Islamic Studies, Vol. 21, No. 1, 2017.

Maskur, Abu. "Pengutan Budaya Literasi di Pesantren," IQ (Ilmu Al-qur'an): Jurnal Pendidikan Islam, Vol. 2, No. 1, 2019.

Minardi, Anton. "The New Islamic Revivalism in Indonesia Accommodationist and Confrontationist," Journal of Indonesian Islam, Vol. 12, No. 2, 2018.

Murariu, Mihai dan George Anglitoiu. "The Case of Islamic State as a Renovative Totalist Movement The Case of Islamic State as a Renovative Totalist Movement," Terrorism and Political Violence, 2019.

Nashir, Haedar. Gerakan Islam Syariat: Reproduksi Salafiyah Ideologis di Indonesia. Jakarta: PSAP Muhammadiyah, 2007.

Nuraniyah, Nava. "Not Just Brainwashed: Understanding the Radicalization of Indonesian Female Supporters of the Islamic State," Terrorism and Political Violence, Vol. 30, No. 6, 2018.

Nurdin, Ali dan Maulidatus Syahrotin Naqqiyah. "Model Moderasi Beragama Berbasis Pesantren Salaf," Islamica: Jurnal Studi Keislaman, Vol. 14, No. 1, 2019. 
Rosdiawan, Ridwan. "Memetakan Anatomi Diskursus Islamisme dan Terorisme Islam," Islamica: Jurnal Studi Keislaman, Vol. 13, No. 1, 2018.

Salik, Mohamad. "Conserving Moderate Islam in Indonesia: An Analysis of Muwafiq's Speech on Online Media," Journal of Indonesian Islam, Vol. 13, No. 2, 2019.

Samudra, Imam. Aku Melawan Teroris. Solo: Al-Jazeera, 2004.

Shodiq, M. "Pesantren dan Perubahan Sosial," Jurnal Sosiologi Islam, Vol. 1, No. 1, 2011.

Ṭayyib (al), Shaykh Ahmmad. Jihad Melawan Teroris; Meluruskan Kesalapaham tentang Khilafah, Takfiri, Jihad, Hakimiyah, Jahiliyah, dan Ekstrimisme (Jakarta: Lentera Hati, 2016), 31-33.

Umam, Fawaizul. Reposisi Islam Reformulasi Ajaran. Mataram: LEPPIM, 2011.

Zainiyati, Husniyatus Salamah. "Curriculum, Islamic Understanding and Radical Islamic Movements in Indonesia," Journal of Indonesian Islam, Vol. 10, No. 2, 2016.

\section{Wawancara}

Abdul Nasir. Wawancara. Banten, 4-20 Agustus 2019.

Anwar. Wawancara. Bima, 4-18 Agustus 2019.

KH. Khatibul Umam. Wawancara. Banten, 4-20 Agustus 2019.

Syamsul Huda. Wawancara. Bangil, 4-20 Agustus 2019.

Ustaz Zaber. Wawancara. Bima, 27 Juli 2019. 